International Journal of Small Business and Entrepreneurship Research

Vol.4, No.6, pp.53-66, November 2016

Published by European Centre for Research Training and Development UK (www.eajournals.org)

\title{
AGRIPRENEURSHIP CURRICULUM DEVELOPMENT IN NIGERIAN HIGHER
} INSTITUTIONS

\author{
Sunday C. Eze ${ }^{1}$ and Vera Chinedu-Eze ${ }^{2}$ \\ 1 Landmark University, Kwara State, Nigeria, \\ 2Micheal Okpara University of Agriculture, Umudike, Abia State, Nigeria,
}

\begin{abstract}
Sustainable agriculture has remained a subject of debate in Nigeria for decades without tangible results. Between 2001 and 2007, agricultural sector accounted for 40 percent of Nigeria's Gross Domestic Products (GDP) and 51 percent of job creation. However, in 2015 agriculture accounted for only 17.77\% of Nigeria's GDP (National Bureau of Statistics, 2015). These figures are indications that agriculture has not met the need of the country, and reveal the dwindling nature of the sector. The declining nature of agriculture calls for a new strategy that will support agricultural development in Nigeria. This paper aims to advance agripreneurship education in Nigerian Universities by attempting to develop a curriculum that will trigger agriprenuership taught classes in Universities in Nigeria in attempt to increase youth and farmers participation in agripreneurship and improve the agricultural sector in general.
\end{abstract}

KEYWORDS: Entrepreneurship, Agripreneurship, Development, University, Nigeria

\section{INTRODUCTION}

Nigeria is undoubtedly rich in natural resources; however, it has remained underdeveloped. Although the country depends mostly on crude oil for its foreign exchange, it is primarily an agrarian society. Agriculture is the prime mover of Nigerian economic growth. It has created employment opportunities, served as important sources of raw materials and has employed about two third of Nigerian labour force (Uneze, 2013). Between 2001 and 2007, the sector accounted for 40 percent of Nigerian's Gross Domestic Products (GDP) and 51 percent of job creation, however, in 2015 agriculture accounted for only $17.77 \%$ of Nigeria's GDP (National Bureau of Statistics, 2015). 
International Journal of Small Business and Entrepreneurship Research

Vol.4, No.6, pp.53-66, November 2016

Published by European Centre for Research Training and Development UK (www.eajournals.org)

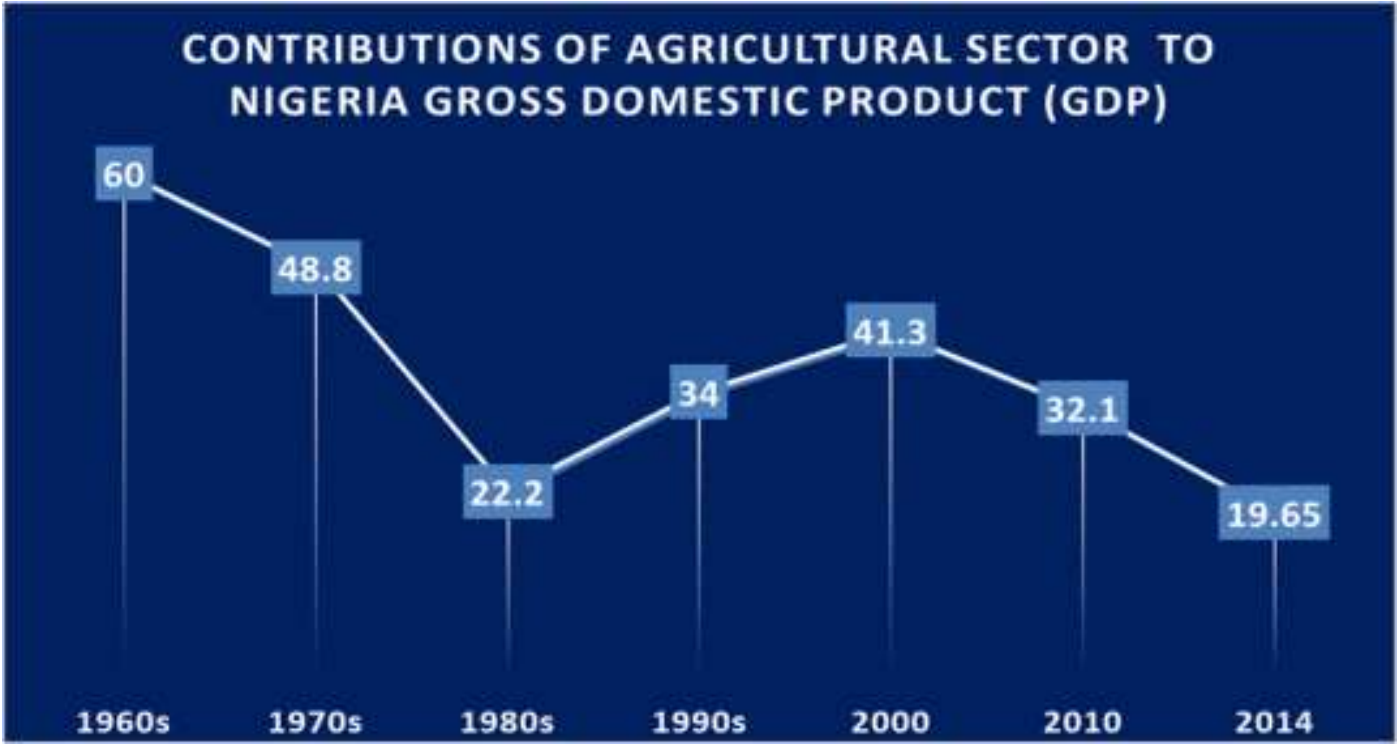

Figure 1: National Bureau of Statistics Quarterly Report, 1960 - 2014

Similarly, data drawn from the National Bureau of Statistics reveals that the service sector accounted for the largest share of the GDP in the first quarter (Q1) 2014, amounting to $\mathrm{N} 8,181,239.94$ million or $52.99 \%$. Industry ranked second with a contribution of $\mathrm{N} 4,223,469.13$ million or $27.36 \%$, whilst agriculture constituted the smallest, representing N3,033,970.43 million or 19.65\% of GDP(National Bureau of Statistics, 2015). In addition, Ayodele et al (2013) noted that Nigeria has 75 percent of its land suitable for agriculture, but only $40 \%$ is cultivated.

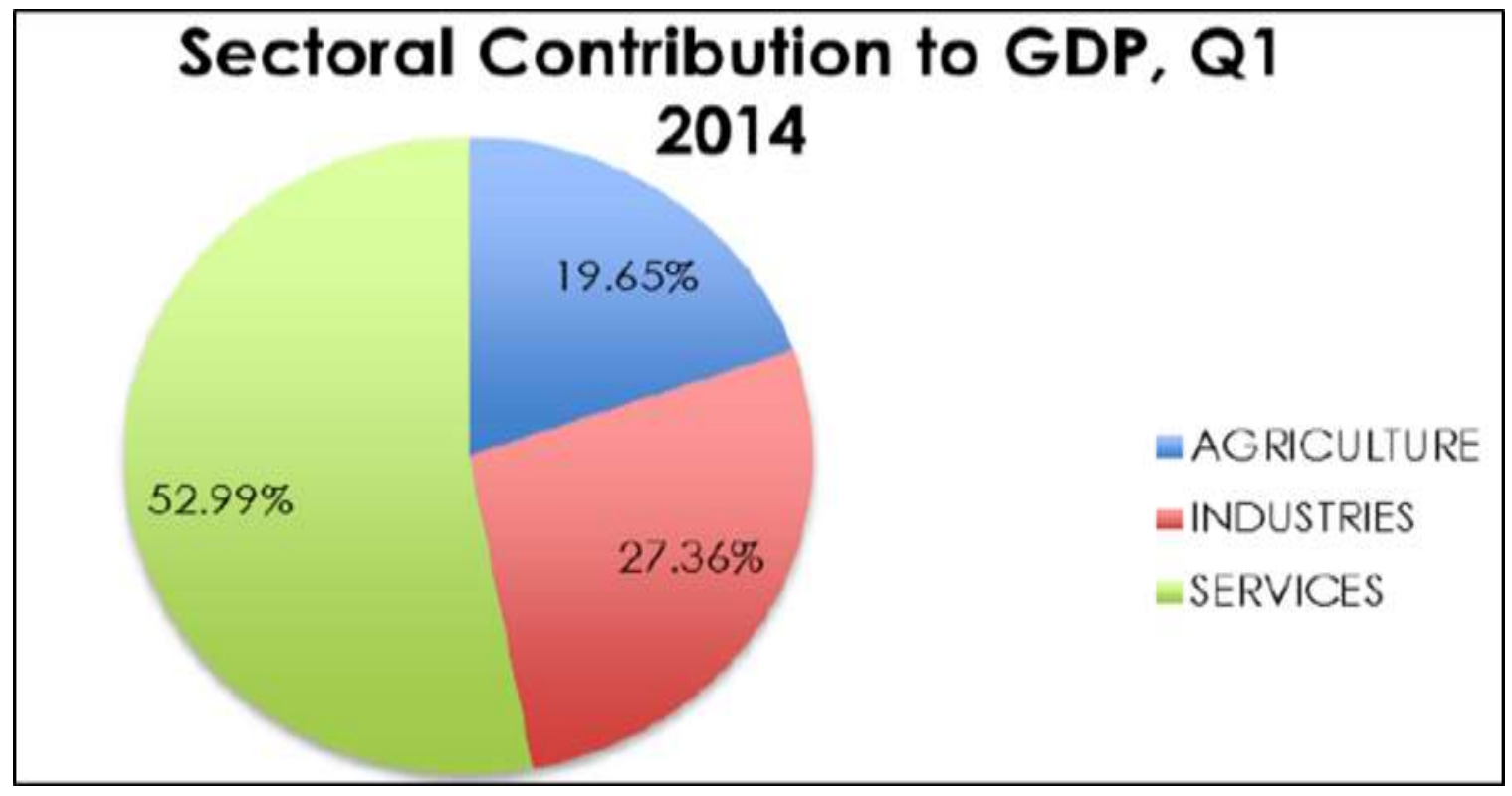

Figure: 2 Sectorial Contribution to Nigeria's National GDP 
These figures indicate that agriculture has not met the need and expectation of the country, and reveal the underperforming level of the sector. The declining nature of agriculture calls for a new strategy that will support agricultural development in Nigerian Universities, which is presently hindered by problems of inadequate technology, poor organization, and management of research, education, training and extension systems (Uneze, 2013).

Nigerian school leavers entering the workforce today expecting white collar jobs and high salaries may be disappointed given that today's job insecurity is almost affecting every business and industry. Many jobs created today are beneath the wage pyramid, thousands of white collar jobs are disappearing and most of the employers now engage temporary workers. In spite of these worrying situations, little or no effort has been made to embrace the concept of agripreneurship in taught and practical classes in Nigerian higher institutions, which is becoming increasingly vital for the social-economic upliftment of greater population through the creation of agribusiness (Sancho, 2010; Singh, 2013; Uneze, 2013). The recent rate of unemployment, level of poverty and depleting form of agricultural activities in Nigeria indicate that there is a dire need to tap into the opportunities for promoting agripreneurship in a way that is sustainable. Therefore, the integration of entrepreneurial skills and knowledge into modern agricultural practices is necessary to produce entrepreneurs and workforce to cater for agricultural enterprises in Nigeria and beyond. This will in turn address the present problem associated with agricultural production since enterprise development is arguably more sustainable than economic development strategies of business attraction and business retention (Sancho, 2010).

This paper attempts to develop an agripreneurship curriculum that may be considered or finetuned and adopted by Nigerian Universities to increase innovative agricultural practices and youth participation in agriculture and advance Nigerian's agricultural sector. The paper is structured as follows: First, it looks at basic terminologies related to agriprenuership development. Second, it stresses on why agricultural entrepreneurship is vital and further examines the need for agripreneurship development. Finally, the paper attempts to develop agriprenuership curriculum that may be considered as one of the future pathways for Nigerian Universities.

\section{BASIC TERMINOLOGIES RELATED TO AGRIPRENUERSHIP DEVELOPMENT}

Entrepreneurship has a long history and has been defined in various ways. The term entrepreneur originated in France in 17th and 18th century. In 19th Century entrepreneurship was defined as the adventurous individual who stimulates economic progress by finding new and innovative ways of accomplishing a task (Singh, 2013). Entrepreneurship is associated with discovering innovative ways to establishing and sustaining a profitable venture. Entrepreneurship and agriprenuership are terms commonly used in the context of education and small business formation in agriculture (Bairwa, 2014; Tripathi and Agarwal, 2015). According to Dollinger (2003), entrepreneurship in agriculture is the creation of innovative ventures for the purpose of growth and gain under conditions of risk and uncertainty in agriculture. Similarly, Hisrich et al, (2008) looked at entrepreneurship as the process of creating something new with value by devoting the necessary time and effort, assuming the risk, and receiving the results, a reward of monetary and personnel satisfaction and independence. 
Published by European Centre for Research Training and Development UK (www.eajournals.org)

On the other hand, agripreneurship is a concept specific to agriculture and draws extensively from entrepreneurship. It is the profitable marriage of agriculture and entrepreneurship and refers to agribusiness development in agriculture and allied sectors (Uneze, 2013; Bairwa, 2014). An agripreneur therefore, is an individual who performs a number of activities in agriculture and allied sector to become an agripreneur. An agriprenuer for example, may start an agro business, change the direction of the business, establish a business or involve in innovative activities of value addition (Tripathi and Agarwal, 2015). In other words, an agriprenuer always try to engage in new products, processing and marketing because such individual is never satisfied with the conventional methods of doing things (Tripathi and Agarwal, 2015; Uneze, 2013; Bairwa, 2014).

Drawing on the above definitions, agripreneurship is defined as the integration of entrepreneurial and innovative business ideas and skills into agriculture to produce better results. Agripreneurship involves innovative ways of cultivation, planting, application of fertilizer, processing of harvested farm produce and converting such into finished products, and conveying them to the point of sales with the use of unique promotional efforts. As identified by Bairwa et al (2014) this explanation demonstrates that agripreneuship is linked to various segments such as input, processing, transportation and marketing.

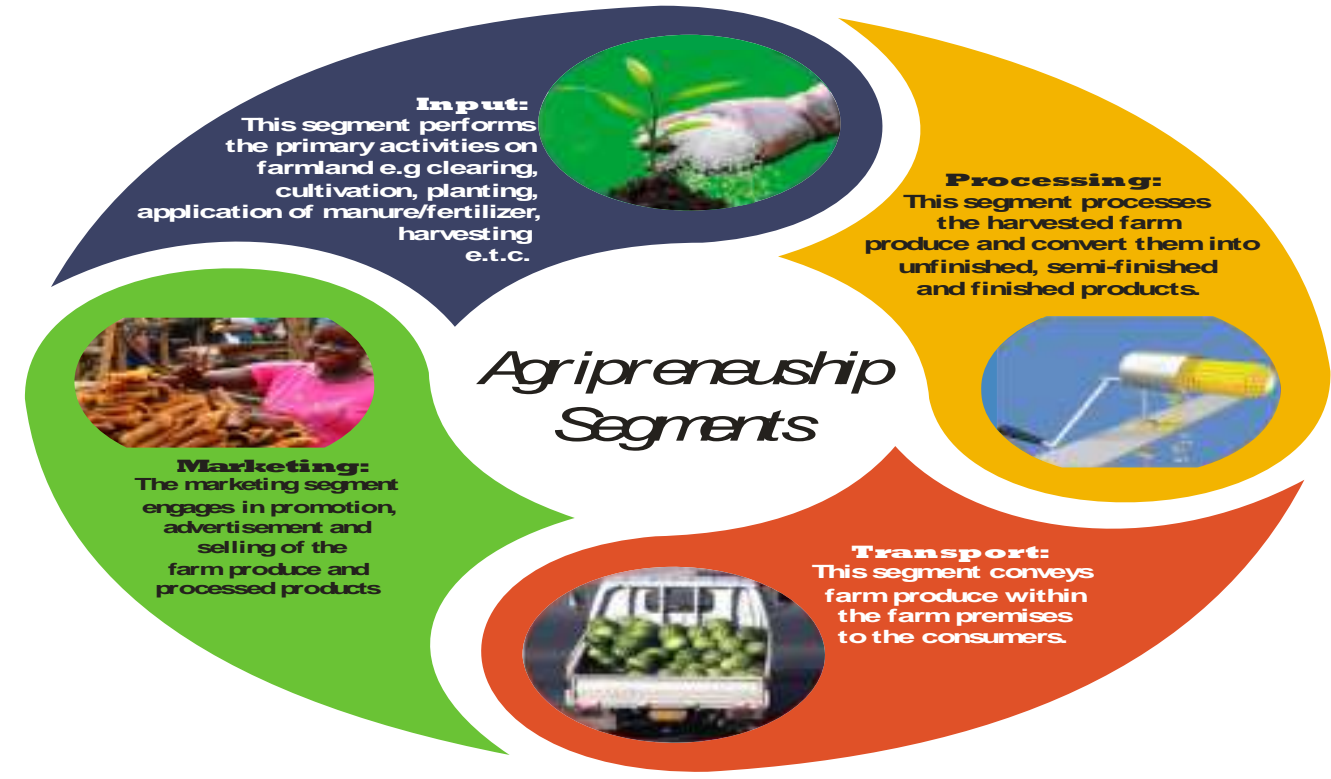

Figure 3: Agripreneurship Segments

Agripreneurship therefore, is directly related to industry, commerce and trade, and involves both on farm activities, and off-farm activities. On-farm activities (e.g production, processing, farm input manufacturing and agro-service ventures) are activities carried out directly on the farmland or its premises. While off-farm activities (e.g agri-tourism entrepreneurship) are farm related undertakings carried outside the farmlands which involve the usage and consumption of agricultural produce. Hence, an agripreneur is a dynamic business manager who is creative, 
International Journal of Small Business and Entrepreneurship Research

Vol.4, No.6, pp.53-66, November 2016

Published by European Centre for Research Training and Development UK (www.eajournals.org)

innovative and performs various on-farms and off-farms activities using human and financial resources in order to achieve positive results.

\section{Need for Agripreneurship Development in Higher institutions in Nigeria}

Over the years, agriculture is seen as a low technology industry with limited dynamics controlled by many small family businesses. These businesses look at doing things better instead of engaging in innovative methodologies. This situation has increasingly changed due to emergence of economic liberalization, and dynamic changes in the environment. Agricultural firms have to adapt to changes in the market, tastes, consumer habit, and enhanced environmental regulation, new requirements for product quality and food security. These changes have constantly paved way for new entrants, innovation and portfolio of free enterprise (Nagalakshmi and Sudhakar, 2013).

Globally, agriculture is going through a transformation, this transformation is not only enabled by innovative minds and technologies, but the fact that countries are recognising that agriculture is taking a new dimension and expanding its scope beyond mere cultivation of crops and rearing of animals for the livelihood of rural population. Nagalakshmi and Sudhakar (2013) stress that issues of diversification, value addition, high technology agriculture, agripreneurship, global marketing are gradually getting due attention in redefining agriculture. Farmers who are unaware of scientific agriculture and effective agri management system will not cope especially with the recent climate change experienced across the globe. Agriprenurship therefore, is an employment strategy that can lead to self-reliance. Agripreneurship development through education and training is a key to making transition from employment to self -employment particularly for the first generation of agriprenuers (Nagalakshmi and Sudhakar, 2013; Bairwa, 2014). The managerial, technical and innovative skills of entrepreneurship if applied in the field of agriculture may yield positive results, and well trained entrepreneurs that may become role models to others (Bairwa, 2014). It is therefore, expedient to instill the skills and knowledge of agripreneurship in our undergraduate to help them identify existing opportunities and create new ones in agriculture; leading to development of novel agribusiness concepts, creation of job opportunities, resuscitating the interest of youth towards agribusiness in Nigeria and fostering the aspiration of youth empowerment in various dimensions. These could result to improvement of rural infrastructure which may in turn encourage the growth and development of non-agricultural business activities.

In an agrarian society like Nigeria where efforts have been made to emphasis on food security, growing farm yield, the country has continuously witnessed growing farmers' suicide and ever bulging farm debt (Sanjog, 2014). Despite the effort of government agencies such as the National University Commission (NUC) in developing curriculum in agriculture and entrepreneurship at different levels, no attempt has been made to develop a system devoted at looking at agriprenurship development in Nigeria Universities. As one that will be a departure philosophy, this paper attempts to develop a curriculum that will help educate, train and develop farmers, students, faculty, staff of various universities in Nigeria in agriprenuership 
International Journal of Small Business and Entrepreneurship Research

Vol.4, No.6, pp.53-66, November 2016

Published by European Centre for Research Training and Development UK (www.eajournals.org)

in a manner that will ensure sustainable agricultural development in Nigeria. This is necessary because. These Centres include:

\section{A. Agri-biotechnology Centre}

- Agricultural biotechnology is a collection of scientific techniques used to improve plants, animals and microorganisms.

- The main aim of Landmark Agri-biotechnology Centre is to develop crops with high level of tolerance against cold, heat and salinity.
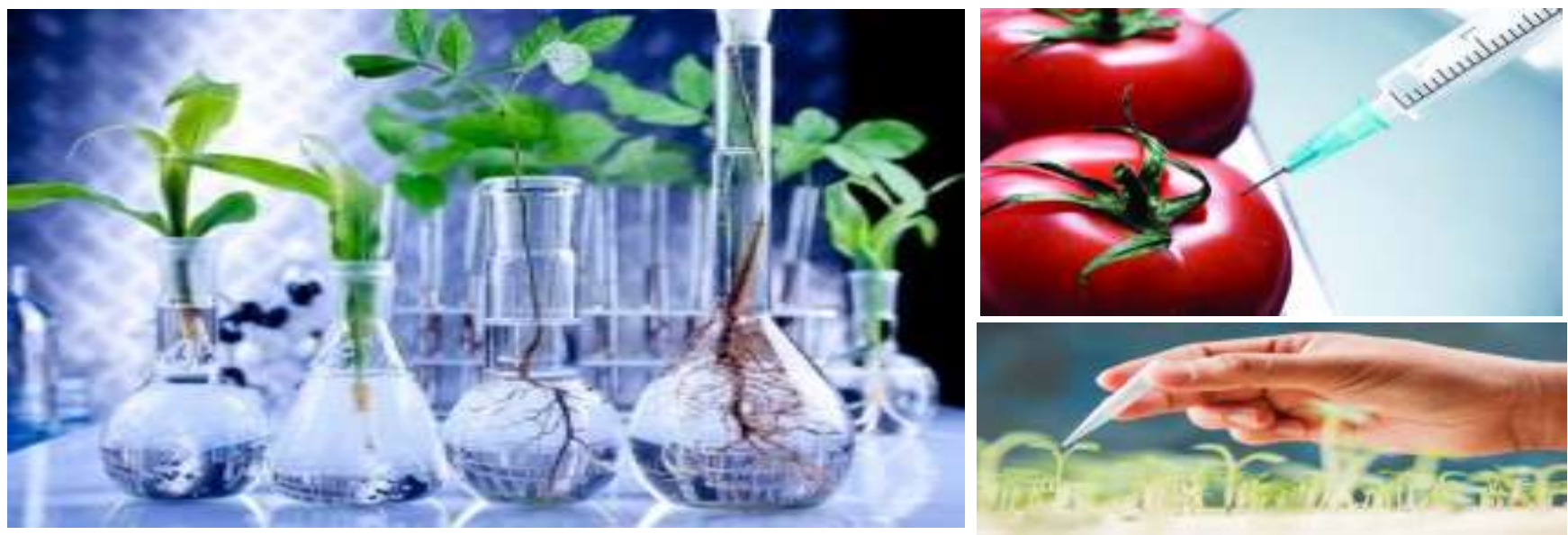

Figure 4: Agri-biotechnology

\section{B. Agri-Clinic Centre}

- Agri-clinics provide expert services and advice to farmers on cropping practices, technology dissemination, crop protection from pests $\&$ diseases, market trends and prices variation of crops.

- Also the unit provides clinical services for animal health which would enhance productivity of crops/animals. These Centres are domicile at the College of Agricultural Sciences and the Department of Agricultural Engineering. 

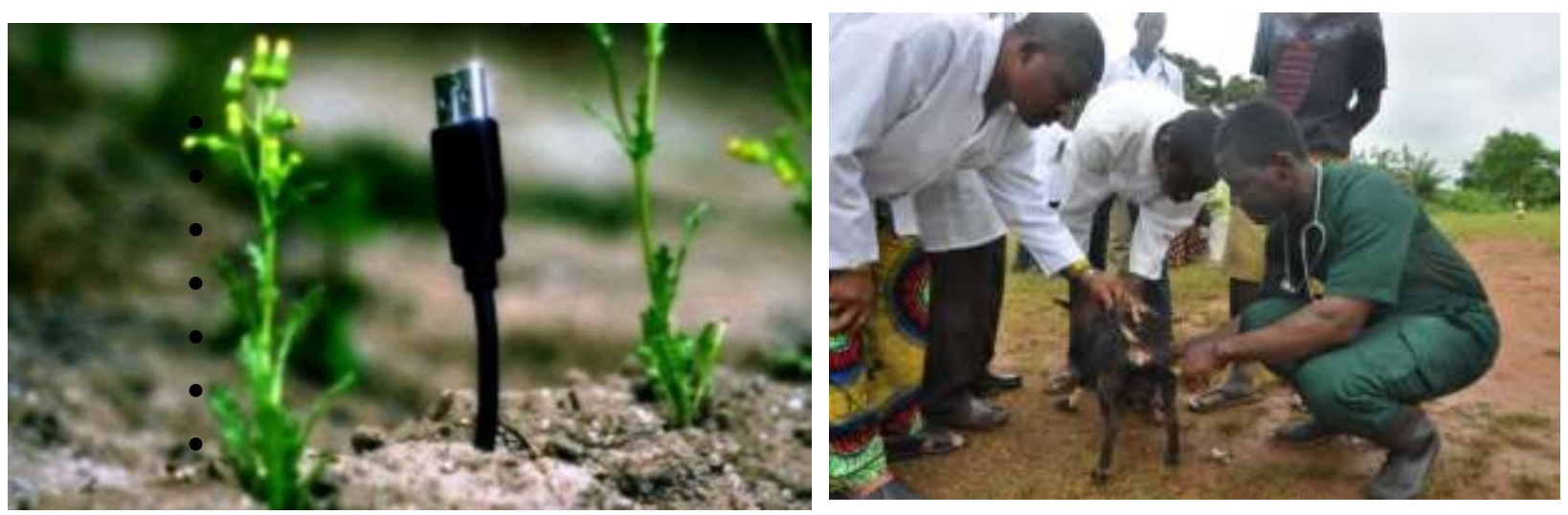

Figure 5: Agri-Clinic Centre

\section{Farm Business School}

- It is essentially a forum for sharing knowledge between farmers (teachers who are specialist in agriculture) and students through discussion, practical exercises and self-study.

- A farm business school is a programme of learning designed to help students and staff who are just getting involved in producing and need help in making it work profitably. These outfits are indication that efforts should be intensified to develop a curriculum that will enhance teaching, research and training in this area to support agricultural development in Nigeria.

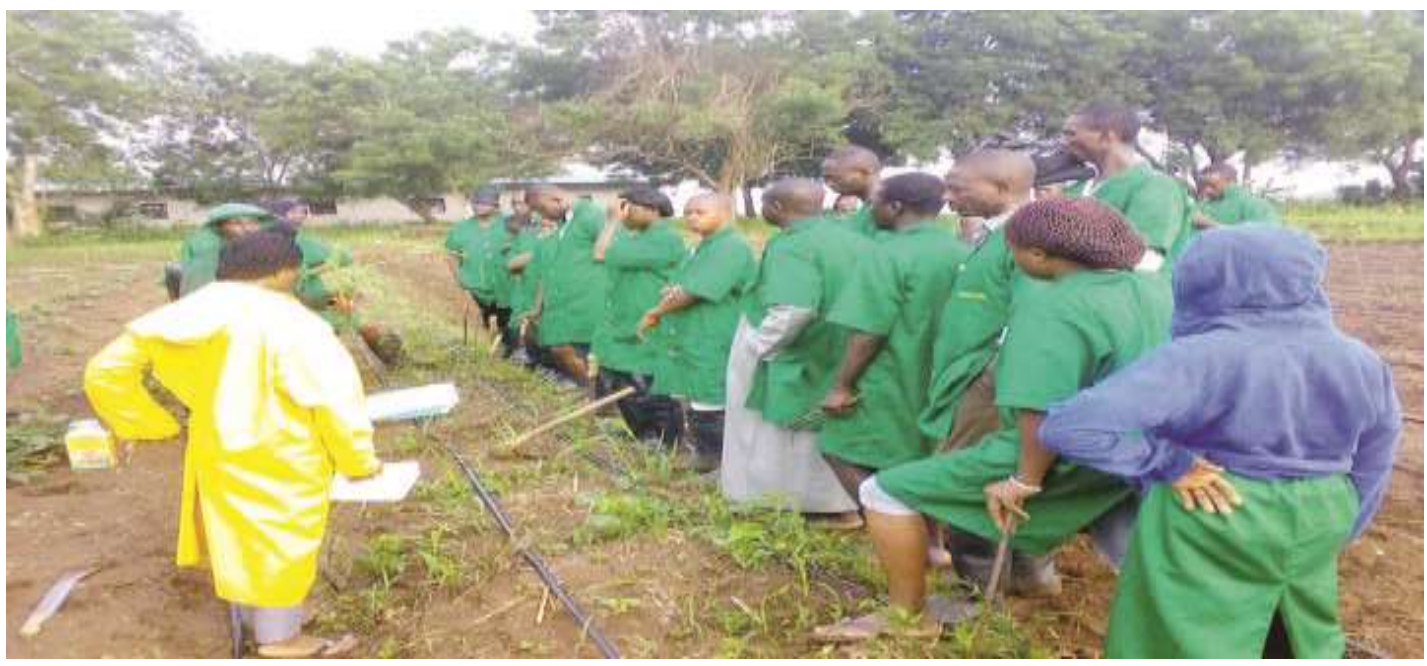

Figure 6: Farm Business School 
International Journal of Small Business and Entrepreneurship Research

Vol.4, No.6, pp.53-66, November 2016

Published by European Centre for Research Training and Development UK (www.eajournals.org)

\section{THE WHY OF THE AGRIPRENEURSHIP CURRICULUM}

Hall et al (2003) stressed that some of the challenges influencing agribusiness curriculum design and instructional methodologies over the last two decades include fewer people in society understanding agriculture, low agricultural experiences by students, and the fact that producers, processors and distributors are becoming sophisticated. In addition, it has been acknowledged that human resources are becoming increasingly important and that international dimension must be incorporated into the curriculum. The ultimate challenge is deciding how best to develop the curriculum and undertake teaching in this new area.

Furthermore, agricultural business experts always identify a set of skills and qualities required of agricultural college graduates. These include leadership, oral and written communication skills, ability to work with people of different countries, critical thinking and problem solving skills (Litzenberg and Schneider, 1987; Hall, 2003). Also companies today look for graduates that possess knowledge of current issues and problems as well key traits such as motivation and management skills. Therefore, agriprenurship curriculum in Landmark University should focus on a complete integration of agriculture and enterperneurship that will provide students with a rich contextual framework that connects theory and practice to enhance students learning experiences. Such curriculum should be taught in the final year, easing the transition between academic experience and entry into a career (Hall et al, 2003). Developing agripreneurship curriculum is critical to agricultural development, whether at the undergraduate or graduate level and for it to achieve the desired outcome, learning activities must be designed, coordinated, and facilitated in a manner that will differ from other paths in the agribusiness curriculum (Hall et al, 2003).

Hence, subsequent section centers on a model designed by the Center for Entrepreneurial Development Studies, Landmark University on agriprenurship curriculum-a customized teaching and practical training model that may be deployed to advance a School for Agriprenurship Development (SAD) in Landmark University.

\section{COMPONENT OF AGRIPRENEURSHIP DEVELOPMENT MODEL IN NIGERIAN UNIVERSITIES}

Drawing on the work of Metha, (2014) and Hall et al (2003), components of Landmark University teaching and training for agripreneurship development could be examined on the basis of the following: 


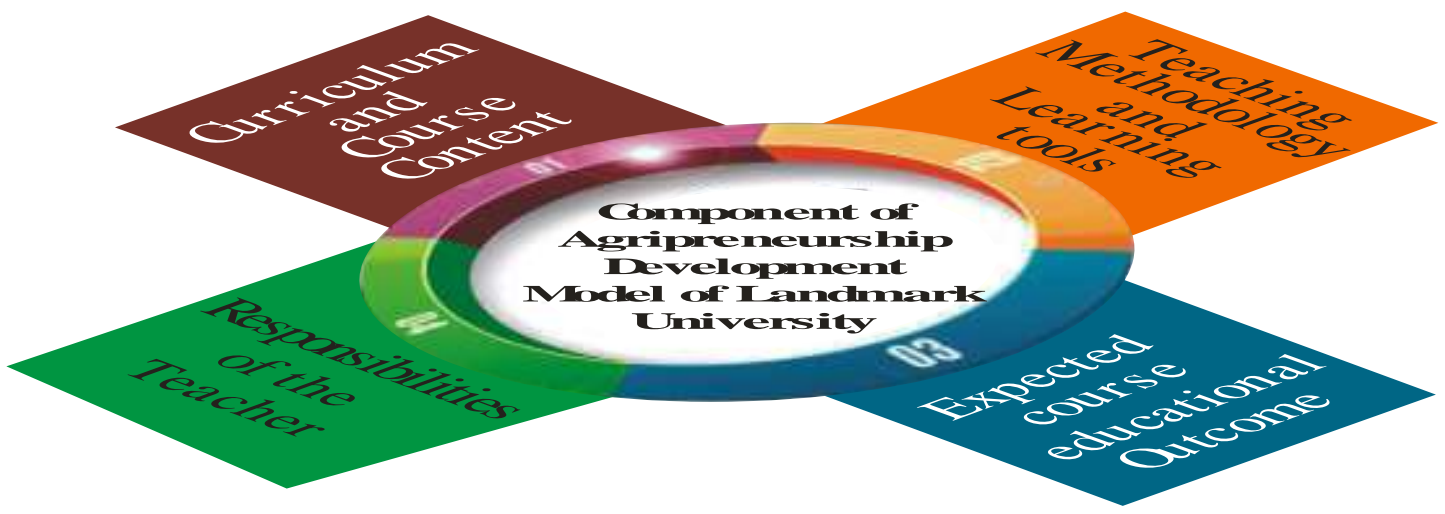

Figure 7: Component of Agripreneurship Development Model in Nigerian Universities

\section{Curriculum and Course content}

\section{Objective}

To contribute in developing paradigm shift by focusing on the young farmers.

To develop agripreneurship skills among youth and farmers

To impact knowledge of agri-project planning

To improve social economic situation of Landmark University Farms community

\section{The curriculum is divided into two sections}

\section{SECTION A}

This section centers on farm management, factors in farm analysis and farm planning, agricultural projects, institutional aids for agriculture and rural development, farm model, contemporary issues related to agriculture.

\section{Farm Management}

Students should be taught agriculture production economy in relation to farm resources, capital, managerial factors, land resources and entrepreneurial resources.

\section{Key Factors in Farm Analysis and Farm Planning}

Appraisal of farm resources, capital, managerial factors, land resources and entrepreneurial resources

\section{Agricultural Projects:}


International Journal of Small Business and Entrepreneurship Research

Vol.4, No.6, pp.53-66, November 2016

Published by European Centre for Research Training and Development UK (www.eajournals.org)

Preparation of Feasibility Report after considering different functional areas of farm management

\section{Institutional Aids for Agriculture and rural development:}

Role of different government and non-government organisation, finance, technical, marketing and advisory support provided by different organisation

\section{Farm Model:}

Contract farming, co-operative farming, collective farming, organic farming, export oriented farming

\section{Contemporary issues related to agriculture:}

Change in government policies, marketing conditions, financial aspect, technology and production related aspect, local factors affecting agriculture and international changes relating to agriculture.

\section{SECTION B}

This section looks at the meaning of entrepreneurship and agripreneurship, psychological, sociological, managerial and economical aspect of entrepreneurship development, need for agripreneurship, role of agripreneurship in national economy, general entrepreneurial skills for a farmer, challenges facing agripreneurs and remedies, strategies for promoting successful agripreneurship and approaches to building agripreneurship capacity in Nigeria

\section{Meaning of Entrepreneurship and Agripreneurship}

Meaning of entrepreneurship and agripreneurship, meaning of entrepreneurs, role of entrepreneurship in agricultural development, traits of an agricultural entrepreneur and scope of entrepreneurship development in agriculture,

\section{Psychological, Sociological, Managerial and Economical aspect of Entrepreneurship Development}

Students should be taught contributory theories of different social sciences and their application to agripreneurship development 
International Journal of Small Business and Entrepreneurship Research

Vol.4, No.6, pp.53-66, November 2016

Published by European Centre for Research Training and Development UK (www.eajournals.org)

\section{Role of Agripreneurship in National Economy}

Areas of entrepreneurship development in agriculture, areas of agro produce processing production units, areas of agro produce manufacturing units, areas of agro input manufacturing units, area of agro Services Centre, and miscellaneous area

\section{Stages of Agripreneurship Development}

Establishment, survival, early growth, rapid growth and maturity stage

\section{General Entrepreneurial Skills for a Farmer}

Taking initiative, ambitions, focused, problem solving, creative thinking, flexibility and adaptability, interpersonal ability, networking and readiness to learn

\section{Challenges Facing Agripreneurs and Remedies}

Lack of fund, lack of infrastructure, risk, marketing problem/competition.

Management Problem: Lack of technological dissemination, legal formalities/regulations, availability of resources, lack of technical knowledge, quality control, low skill level among farmers. Remedies: Establishment of financial aid, concessional rate of interest, suitable supply of raw materials, setting training facilities, setting up market co-operatives

\section{Strategies for Promoting Successful Agripreneurship}

Development of polices that will be fully supported by policy changes, agripreneurship education at school level with proper focus on the curriculum and training teachers, policy makers should look at agriprenuership as wealth creating mechanism, breeding of local agripreneurs, policy makers should assist farmers in becoming agripreneurs, improve capacity building of farmers by training and re-training.

\section{Approaches to building Agripreneurship Capacity}

Technical and vocational education and training, learning from direct experience, workforce development, transfer of technology 
International Journal of Small Business and Entrepreneurship Research

Vol.4, No.6, pp.53-66, November 2016

Published by European Centre for Research Training and Development UK (www.eajournals.org)

\section{Responsibilities of the Instructor}

- Assignment large term-long project, case studies, and issues analyses

- Requiring intensive writing and speaking

- Including Department Faculty in course formulation and teaching

- Using critical thinking to solve real word problems

- Holding open class discussion

- Involving guest speakers

- Conducting field trips

- Team teaching selection topics or the entire course

- Using Faculty peer evaluation

- Inviting student feedback

- Ensure that students study and keep abreast of current events

- Using debates in class

- Presenting final project results to real clients or representatives from industry

- Establishing deadlines on course projects throughout the term

\section{Teaching Methodology and Learning Tools}

- Projects, case studies, or issue analysis

- Small group work including 3-5 students undertaking an assignment or team paper

- In-class oral communication activities

- Intensive writing assignments

- Introduction of industry representatives to students in a planned learning environment
Expected Course

\section{Educational Outcomes}

- Problem solving

- Decision-making abilities

- Capacity for critical thinking

- Ability to develop collaborative and professional relationship

- Oral and written communication

- $\quad$ Prepare students for careers

- Improve awareness of complex relationships between societies, cultures and business

- Facilitate transition from college to the workplace

Figure 8: Attributes of Agripreneurship Taught Course

Source: Adapted from Hall et al (2003)

\section{Course Duration}

Agripreneurship curriculum should be taught in the final year either at 400 level or 500 level, easing the transition between academic experience and entry into a career. The course can be administered two hours in a week and it is expected to be covered within 12 to 13 weeks. In other words, the entire course can be covered within 26 hours. For this to be effective, the university should adopt the following strategy:

Awareness: Students should be made aware of the various on-farm and off-farm opportunities that exist, and that with adequate skills and knowledge, they might become owners and managers of agri businesses.

Exploration: Students should at Alpha Semester vacations be placed in businesses to gain experience, observe the requirements for business operations and visit business owners and operators, while studying various aspects of agricultural businesses in the class 
International Journal of Small Business and Entrepreneurship Research

Vol.4, No.6, pp.53-66, November 2016

Published by European Centre for Research Training and Development UK (www.eajournals.org)

Preparation: Students at this stage should be encouraged to establish supervised agricultural experience programmes in agripreneurship

\section{Performance Evaluation}

The performance evaluation for this course should be an integration of formal and informal methods. According to Metha (2014), this involves assessment of projects prepared through team-work, stimulation, games and case studies, scrutinizing the development of entrepreneurship skills by evaluating the performance of the trainee students on the job comparing with the past performance and change in behavioural and psychological aspect with the help of psycho-behavioural and motivational; tests.

\section{CONCLUSION}

For agriprenusrship education to be felt across Nigerian Universities should be affiliated with research and development institutes and government agencies. This will not only help in awarding certificate to farmers but also bring authentication and value to the course (Metha, 2014). The proposed course does not suggest any shift from the curriculum and personnel for teaching and learning at affected level, however, it is a call to advancing agricultural sector by introducing a creative and innovative approach to agriculture in Nigeria.

\section{REFERENCES}

Bairwa S. L., Lakra K.,Kushwaha S., Meena L.K., AND Kumar P (2014) Agripreneurship Development as a tool to upliftment of Agriculture, International Journal of Scientific and Research Publications, Vol.4,No.3,pp.1-4

Hall C.R, Fairchild G.R., Baker G.A., Taylor T.G and Litzenberg K.K (2003) Agribusiness Capstone Courses Design: Objectives and Strategies, International Food and Agribusiness Management Review Vol.6,No.4,pp.47-62

Hisrich R.D and Peter M. P. (2002) Entrepreneurship, Mg Graw Hill Higher Education, New York USA

Metha S.S.(2014) Institute for Entrepreneurship Development Amongst Farmers-Especially Small and Marginal Land Holders, Global Journal for Research Analysis, Vol.3, No.9, pp.132-134

Nagalakshmi T. and Sudhakar A. (2003) Agri-Preneurs: A Case of Dharmapuri Farmers, International Journal of Science and Research, Vol. 2, No.8, pp.208-214

National Bureau of Statistics (2014) Nigerian Gross Domestic Product report, Quarter one

National Bureau of Statistics (2015) Nigerian Gross Domestic Product report Expenditure Approach. Quarter one 
International Journal of Small Business and Entrepreneurship Research

Vol.4, No.6, pp.53-66, November 2016

Published by European Centre for Research Training and Development UK (www.eajournals.org)

National Bureau of Statistics (2015) Nigerian Gross Domestic Product report, Quarter three

Sancho F.(2010) Agricultural and Rural Entrepreneurship : Concepts for Modeling Development, Comunica, July

Singh A.P. (2012) Strategies for Developing Agripreneurship among Farming Community in Uttar Pradesh, Journal of Asia Entrepreneurship and Sustainability Vol.8, No.1pp. 81102

Singh A.P. (2013) Factors Influencing Entrepreneurship among Farming Community in Uttar Pradesh, International Refereed Research Journal Vol.4, No.3, pp.114-121

Tripathi R. and Agarwal S.( 2015) Rural Development through Agripreneurship : A study of Farmers in Uttar Pradesh, Global Journal of Advanced Research, Vol.2, No.2, pp.534542

Uneze C. (2013) Adopting Agripreneurship Education for Nigeria's Quest for Food Security in Vision 20:2020, Greener journal of Educational Research, Vo.3,No.9,pp.411-415 